\title{
Peran Serta Masyarakat Dalam Penyelenggaraan Pendidikan
}

\author{
Nova Suci Lestari Pakniany ${ }^{1}$, Ali Imron ${ }^{2}$, I Nyoman Sudana Degeng ${ }^{3}$ \\ ${ }^{1}$ Manajemen Pendidikan-Universitas Negeri Malang \\ ${ }^{2}$ Administrasi Perkantoran-Universitas Negeri Malang \\ ${ }^{3}$ Teknologi Pembelajaran-Universitas Negeri Malang
}

\section{INFO ARTIKEL}

\section{Riwayat Artikel:}

Diterima: 30-08-2019

Disetujui: 09-03-2020

Kata kunci:
public;
organization of education;
masyarakat;
penyelengaraan pendidikan

\author{
Alamat Korespondensi: \\ Nova Suci Lestari Pakniany \\ Manajemen Pendidikan \\ Universitas Negeri Malang \\ Jalan Semarang 5 Malang \\ E-mail: novasucii92@gmail.com
}

\begin{abstract}
This study aims to determine the management of community participation in organizing education in junior high schools. qualitative approach was used in this research with multi-site study design. Through observation, interviews and documentation to collect data. The results of this study indicate that: (1) participation required: thoughts, energy, facilities and goods owned by the community, (2) elements of community participation: KTBT, parents of students, village institutions, religious leaders, ( 3 ) in the program to increase participation by analyzing problems, potentials and needs of the community, (4) recognizing the existence of the community, fostering a sense of belonging, trust, including community leaders in every activity and giving freedom to provide input and advice, (5) level community participation from both schools is still at the level of placation, (6) the results and the impact of community participation are felt by the school and the community itself.
\end{abstract}

ABSTRAK

\begin{abstract}
Abstrak: Penelitian ini bertujuan untuk mengetahui jalanya manajemen partisipasi masyarakat dalam penyelenggaraan pendidikan di Sekolah Menengah Pertama. Pendekatan kualitatif digunakan dalam penelitian ini dengan desain studi multi situs. Melalui observasi, wawancara, dan dokumentasi untuk mengumpulkan data. Hasil dari penelitian ini menunjukkan bahwa: (1) peran serta yang dibutuhkan: pikiran, tenaga, fasilitas dan barang yang dimiliki masyarakat, (2) unsur peran serta masyarakat: KTBT Pulau Damer, orangtua peserta didik, lembaga desa, pemuka agama, (3) dalam program untuk meningkatkan peran serta dengan menganalisis masalah, potensi serta kebutuhan masyarakat, (4) mengakui keberadaan masyarakat, menumbuhkan rasa memiliki, rasa kepercayaan, mengikutsertakan tokoh masyarakat dalam setiap kegiatan dan memberilakn kebebasan dalam memberikan masukan dan saran, (5) tingkat peran serta masyarakat dari kedua sekolah masih berada dalam tingkat placation, (6) hasil dan dampak peran serta masyarakat dirasakan oleh pihak sekolah dan masyarakat itu sendiri.
\end{abstract}

Penyelenggaraan pendidikan dilakukan tidak hanya oleh pihak sekolah, seperti pendidik dan tenaga kependidikan, namun keberadaan masyarakat dan orangtua peserta didik ikut mewujudkan pencapaian pendidikan yang lebih baik. Pernyataan ini sesuai dengan teori yang dipaparkan oleh (Zaini, Zakso, \& Syukri, 2014) bahwa salah satu upaya efektif yang dapat dilakukan untuk memperoleh tujuan penyelenggaraan pendidikan yang baik yaitu dengan melibatkan masyakarat dan orangtua peserta didik. Hal ini diterapkan untuk memperoleh dukungan dan memberikan kesempatan bagi pihak eksternal untuk ikut berperan serta merasakan perkembangan pendidikan di daerahnya. Upaya pengadaan peran serta masyarakat atau orangtua peserta didik seperti yang dipaparkan oleh teori di atas merupakan bagian dari proses desentralisasi pendidikan (Dwiningrum, 2011).

Peran masyarakat tidak hanya dilakukan dengan dukungan yang bersifat materi, namun juga pemikiran, motivasi, serta kerjasama yang terus berjalan melalui pihak komite sekolah, pemberian bahan material atau dana untuk membangun pendidikan yang diberikannya dalam forum rapat sekolah (Lukito, 2012). Pernyataan yang dipaparkan oleh Lukito tersebut memberikan gambaran mengenai peran-peran yang dapat diberikan oleh masyarakat maupun orangtua peserta didik, peran serta tersebut ditujukan untuk membangun kerjasama yang baik antar pihak untuk mencapai pendidikan yang mampu bersaing dalam perkembangan zaman. Oleh karena itu, pihak-pihak yang dimaksud, seperti guru dan orangtua peserta didik harus terjalin dengan baik untuk meningkatkan peran serta yang diharapkan (Pradhan, dkk, 2011). 
Menurut (Noor, 2011) pemberdayaan masyarakat merupakan upaya melibatkan masyarakat dalam hal pembangunan ekonomi, dikatakan sebagai pembangunan ekonomi karena dalam pelaksanaannya tentu melibatkan keberadaan APBD yang digunakan untuk mempermudah pengadaan kegiatan partisipasi. Teori ini memberikan pandangan bahwa peran masyarakat tidak hanya berlangsung dalam aspek permintaan atau pengadaan masyarakat saja, namun banyak hal yang perlu diperhatikan dan sangat penting yang secara langsung dapat memudahkan pelaksanaan kegiatan, salah satu bentuk partisipasi masyarakat adalah dalam pembangunan kebijakan pendidikan, seperti yang dilakukan oleh lembaga pendidikan dan lain sebagainya, (Mariana, 2017). Selain itu, partisipasi masyarakat juga dapat dikatakan sebagai urusan politik karena termasuk pada proses disentralisasi yang dijelaskan sebelumnya, pernyataan ini sejalan dengan teori yang dipaparkan oleh (Magriasti, 2011) bahwa bagian disentralisasi atau pemberian tanggungjawab dalam pembangunan di setiap daerah memiliki tujuan dari berbagai segi seperti politik, manajemen pemerintahan, kemasyarakatan dan ekonomi. Keberadaan disentralisasi dalam dunia pendidikan ini dapat memberikan keluasaan kepada masyarakat untuk berpastisipasi dalam pembangunan pendidikan, salah satunya adalah penyelenggaraan sekolah (Munadi, 2013).

Berdasarkan pada pernyataan di atas diperoleh pemahaman bahwa keikutsertaan masyrakat dan orangtua peserta didik dalam penyelenggaraan pendidikan disebut sebagai proses partisipasi (Imron, 2012). Proses partisipasi atau peran serta masyarakat dan orangtua peserta didik dalam lingkungan sekolah adalah untuk pengambilan masukan, keputusan dan pengumpulan dukungan-dukungan yang membutuhkan persiapan sehingga pembangunan nasional seperti pendidikan dapat terdorong dan meningkatkan mutu sekolah (Laksana, 2013). Pada upaya pelibatan peran serta masyarakat dan orangtua peserta didik, sekolah juga perlu untuk memperhatikan kebutuhan pihak-pihak tersebut sebagai tanggungjawab yang positif sehingga dapat menciptakan lingkungan kerjasama yang baik (Handayani, 2011).

Tahapan partisipasi atau peran serta keterlibatan masyarakat dan orangtua peserta didik dapat berlangsung melalui perencanaan, pelaksanaan dan evaluasi kegiatan, yang mana dalam pelaksanaanya turut terlihat jenis pera serta yang diberikan yaitu dalam bentuk dukungan yang terlihat maupun tidak secara langsung seperti yang dijelaskan oleh Zaini, dkk di atas, (Hermawan \& Suryono, 2016). Teori ini memberikan pemahaman bahwa semua aktivitas, kegiatan dalam bentuk program yang dibangun oleh lembaga pendidikan, termasuk mengenai keterlibatan masyarakat dan orangtua peserta didik perlu untuk direncanakan terlebih dahulu, dan pembentukan pihak-pihak internal sebagai penanggung jawab terlaksananya kegiatan penyelenggaraan pendidikan di daerahnya.

Terdapat banyak faktor yang dapat memengaruhi peran serta atau keterlibatan masyarakat atau orangtua peserta didik dalam penyelenggaraan suatu program, seperti yang dijelaskan oleh (Suroso, Hakim, \& Noor, 2014) yang dikelompokkan ke dalam dua faktor, yaitu internal dan eksternal. Faktor internal, meliputi usia, tingkat pendidikan, jenis pekerjaan, tingkat penghasilan penduduk, dan lama tinggal di suatu daerah, sedangkan untuk faktor eksternal, meliputi komunikasi dan kepemimpinan, komunikasi, dan kepemimpinan yang dimaksud apabila berkaitan dengan penyelenggaraan pendidikan, maka berhubungan dengan komunikasi yang tercipta melalui komite sekolah dengan masyarakat dan orangtua dalam membangun pendidikan melalui kerjasama yang baik.

Melalui proses penyelenggaraan partisipasi masyarakat secara transparansi juga memengaruhi keberadaan APBD (Anggaran Pendapatan dan Belanja Daerah), dengan kata lain pelaksanaan pengadaan partisipasi masyarakat dalam pembangunan pendidikan di daerah juga melibatkan perhitungan mengenai APBD yang dimiliki oleh lembaga pendidikan, hal ini berlangsung untuk menunjang partisipasi yang dimaksud sehingga dapat menguntungkan dua pihak yaitu sekolah dan masyarakat atau orangtua peserta didik secara khusus (Isma Coryanata, 2007). Teori ini memberikan gambaran bahwa penyelenggaraan partisipasi masyarakat tidak berjalan dengan mudah, dalam artian banyak persiapan yang perlu diperhatikan oleh sekolah atau lembaga pendidikan, persiapan yang dimaksud dapat berupa APBD atau anggaran yang dapat memperlancar jalannya kegiatan penyelenggaraan pendidikan, dalam hal ini adalah untuk memudahkan pengadaan pendidikan di beberapa daerah.

\section{METODE}

Penelitian ini menggunakan jenis pendekatan kualitatif dengan tujuan untuk mendeskripsikan secara jelas mengenai partisipasi masyarakat dalam penyelenggaraan sekolah di daerah terpencil yang berlokasi di SMP Negeri 1 Damer dan SMP Kristen Kehli, Kec. Damer Kab. Maluku Barat Daya. Menurut (Moleong, 2016) penelitian ini digunakan untuk memahami fenomena yang dialami oleh suatu subjek penelitian. Analisis data dalam penelitian ini dilakukan dengan analisis studi multi situs. Menurut (Ulfatin, 2015) multisite studies adalah rancangan penelitian yang melibatkan beberapa situs serta beberapa subjek penelitian yang digunakan sebagai kasus yang mana subjek penelitiannya diasumsikan memiliki karakteristik yang relatif sama. Hal ini berdasarkan dari latar belakang kedua sekolah yang memiliki kesamaan tipologi, yakni letak wilayah, latar budaya, tingkat perkembangan, daerah terpencil, pertumbuhan penduduk, dan tingkat ekonomi yang relatif sama. Teknik pengumpulan data dalam penelitian ini, meliputi wawancara mendalam, observasi, dan dokumentasi karena pada umumnya penelitian kualitatif melalui tiga aspek tersebut (Sugiyono, 2014). Analisis data lintas situs dapat dilihat pada gambar 1. 


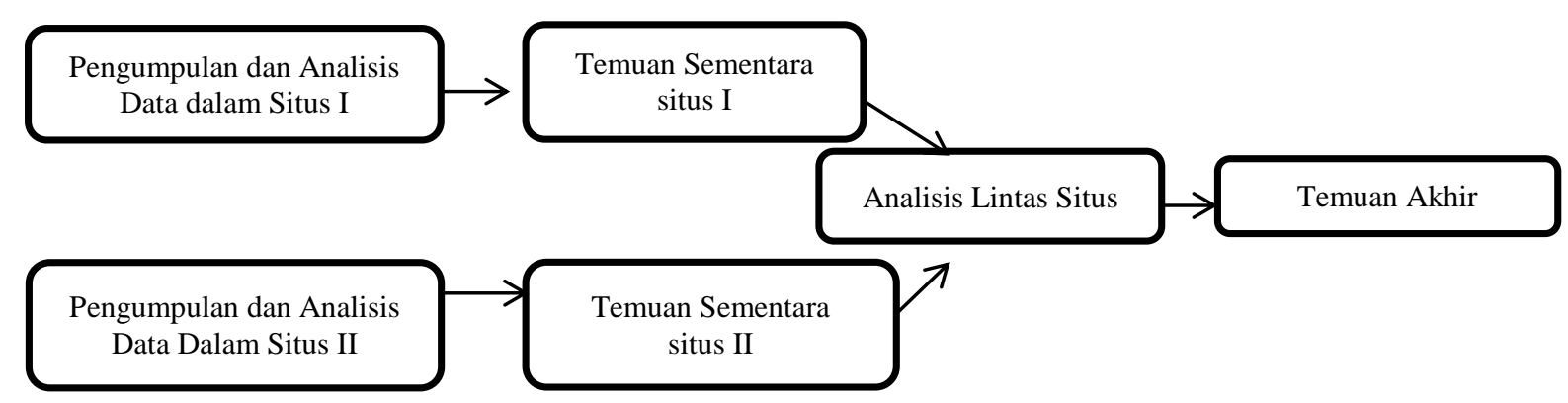

Gambar 1. Langkah-Langkah Analisis Data

Pengecekan keabsahan data yang diperoleh selama penelitian berlangsung diperlukan agar data yang diperoleh benarbenar dapat dipertanggungjawabkan, digunakan tiga kriteria dalam menjaga kebenaran hasil penelitian, yakni kredibilitas (kepercayaan), dependabilitas dan konfirmabilitas Wiersma (dalam Sugiyono, 2014). Tahap-tahap penelitian dilakukan mulai dari tahap persiapan, tahap pelaksanaan, dan tahap pelaporan hasil penelitian.

\section{HASIL}

\section{Temuan Penelitian Situs I}

Berdasarkan pada penelitian yang dilakukan di SMPN 1 Damer ini diperoleh hasil temuan dalam menjawab fokus penelitian. Pertama, jenis partisipasi yang dibutuhkan sekolah dari masyarakat yang meliputi pemberian bantuan berupa dana, tenaga, pikiran, ide dan moral, bantuan-bantuan yang disebutkan ini selanjutnya digunakan untuk membangun sarana sekolah yang dapat menunjang pembangunan pendidikan di daerah tersebut, sarana yang dibangun antara lain ruangan kelas, kamar mandi, dan kantin. Selain itu jenis partisipasi lain yang disebutkan antara lain ide dan pemikiran, bantuan ini secara langsung tidak terlihat dalam pelaksanaannya, namun terkandung dengan terstruktur atau menjadi masukan-masukan yang diberikan oleh masyarakat dan orangtua peserta didik dengan tujuan mengembangkan sekolah di daerahnya. Kedua, unsur-unsur masyarakat yang berpastisipasi antara lain: orangtua peserta didik, kepala Desa Wulur, Komunitas Tiga Bantu Tungku (KTBT) pulau Damer, tokoh-tokoh Agama dan tokoh-tokoh masyarakat yang mempunyai pengaruh di daerah tersebut. Ketiga, pembuatan program perencanaan untuk meningkatkan partisipasi masyarakat oleh SMPN 1 Damer ini dilakukan dengan menganalisis permasalahan pendidikan terlebih dahulu, kedua adalah menganalisis sumber daya yang mampu mendukung terlaksananya pembangunan pendidikan, ketiga adalah menganalisis kemampuan dan kebutuhan masyarakat yang berhubungan dengan keinginan yang diinginkan untuk pengembangan penyelenggaraan pendidikan. Setelah semua dianalisis dengan baik barulah kemudian dibentuk program-program yang dimaksud, disesuaikan dengan APBD atau anggaran yang dimiliki kemudian mengharap bantuan dari masyarakat seperti yang dijelaskan di atas seperti dana dan lain sebagainya, selanjutnya adalah mewujudkan kegiatan yang diprogramkan.

Keempat, teknik-teknik yang digunakan dalam pelaksanaan partisipasi masyarakat pertama kali yang dilakukan oleh lembaga pendidikan adalah dengan menyadari keberadaan masyarakat di daerah sekolah, menumbuhkan rasa memiliki mengenai pentingnya sekolah dibangun dengan baik kepada masyarakat daerah juga termasuk pemberian pemahaman, pengertian dan kesadaran mengenai pentingnya keterlibatan masyarakat untuk menunjang pelaksanaan pendidikan, melakukan kunjungan ke rumah-rumah masyarakat serta pihak yang berpengaruh di daerah tersebut sehingga dengan mudah dalam memberikan pengaruh yang positif kepada masyarakat sebagai pihak umum atau orangtua peserta didik. Kelima, tingkat partisipasi masyarakat yang terjadi adalah sedang (placation), yang bermakna bahwa penyelenggaraan pendidikan di daerah ini dapat dikatakan tidak terlalu sulit dan tidak terlalu mudah, sehingga disebutkan sedang karena baik fasilitas atau upaya memberikan pengaruh kepada masyarakat membutuhkan waktu yang cukup singkat apabila sekolah mengunjungi pihak yang memiliki pengaruh di daerah tersebut. Keenam, hasil dan dampak dari partisipasi masyarakat yang diperoleh di SMPN 1 Damer ini antara ini adanya pembangunan perpustakaan sekolah, kantin, kamar mandi, dan ruangan kelas yang ditambah melalui dukungan-dukungan yang diberikan oleh masyarakat, inilah yang disebut sebagai hasil dan dampak yang dirasakan dari kegiatan partisipasi atau peran serta yang dilakukan oleh pihak-pihak yang disebutkan dalam poin 2 di atas, sedangkan dampak langsung yang dirasakan adalah peserta didik dapat melaksanakan dan mengikuti pendidikan seperti layaknya yang terjadi di sekolah umum baik di kota atau daerah-daerah yang dapat dikatakan lengkap fasilitas dan lain sebagainya. Hal ini tentu dapat menunjang peningkatan mutu pendidikan di sekolah karena setiap pihak turut bekerjasama dalam membangun pendidikan.

\section{Temuan Penelitian Situs II}

Berdasarkan pada penelitian kedua yang dilakukan di SMP Kristen Kehli diperoleh hasil temuan sebagai berikut. Pertama, jenis partisipasi yang dibutuhkan sekolah dari masyarakat, meliputi uang, barang, dan tenaga masyarakat untuk dapat bekerjasama dalam membantu kelancaran pendidikan, salah satunya adalah memperbaiki fasilitas umum yang menjadi satu- 
satunya jalur peserta didik dan guru untuk dapat menjangkau sekolah yaitu jembatan yang berada di atas sungai sehingga dapat memberikan keamanan dan kenyamanan bagi orangtua peserta didik. Selain itu, untuk membangun ruang belajar, ruang guru dan sarana lainnya untuk menunjang pendidikan di sekolah yang dimaksud. Kedua, unsur partisipasi masyarakat antara lain orangtua peserta didik, lembaga desa, Komunitas Tiga Batu Tungku (KTBT) pulau Damer, pemuka Agama dan tokoh-tokoh penting masyarakat. Ketiga, pembuatan program untuk meningkatkan partisipasi masyarakat antara lain diawali dengan menganalisis permasalahan yang muncul, menganalisis potensi yang ada serta kebutuhan sekolah, program yang terealisasi melalui upaya ini adala pembuatan ruang kelas dan kamar mandi. Keempat, teknik pelaksanaan partisipasi masyarakat yang digunakan antara lain dengan memberikan tanggung jawab langsung kepada masyarakat dan orangtua di sekitar sekolah, menyebarluaskan kebutuhan sekolah sehingga membentuk kesadaran masyarakat dan orangtua peserta didik, dan melibatkan tokoh masyarakat yang berpengaruh sehingga memudahkan proses pengadaan program. Kelima, tingkat partisipasi masyarakat di SMP Kristen Kehli ini dapat dikatakan sedang karena dalam pengadaan baik fasilitas maupun keterlibatan masyarakat dan orangtua peserta didik tidak terlalu sulit, karena sekolah melibatkan pihak-pihak yang berpengelaman. Keenam, hasil dan dampak dari partisipasi masyarakat, yaitu dengan adanya pembangunan ruang kelas, ruang guru, dan kamar mandi yang secara langsung menunjang konsentrasi belajar mengajar oleh guru dan peserta didik.

Temuan Penelitan Lintas Situs

Tabel 1. Temuan Lintas Situs Penelitian

\begin{tabular}{|c|c|c|c|c|}
\hline No & Fokus & Temuan Situs I & Temuan Situs II & Temuan Lintas Situs \\
\hline 1 & $\begin{array}{l}\text { Jenis partisipasi yang } \\
\text { sekolah butuhkan dari } \\
\text { masyarakat }\end{array}$ & $\begin{array}{l}\text { Tenaga, pikiran, ide, dana } \\
\text { serta moral }\end{array}$ & $\begin{array}{l}\text { Barang, tenaga serta uang untuk } \\
\text { memperbaiki jembatan, perbaikan } \\
\text { ruang guru, pembuatan ruang kelas } \\
\text { dan pembuatan wc/kamar mandi } \\
\text { bagi guru dan siswa }\end{array}$ & $\begin{array}{l}\text { Pikiran, uang, fasilitas, tenaga } \\
\text { serta barang yang telah dimiliki } \\
\text { oleh warga masyarakat. }\end{array}$ \\
\hline 2 & $\begin{array}{l}\text { Unsur masyarakat yang } \\
\text { turut berpartisipasi }\end{array}$ & $\begin{array}{l}\text { Orangtua peserta didik, } \\
\text { kepala Desa Wulur, KTBT } \\
\text { Pulau Damer, tokoh-tokoh } \\
\text { agama dan warga } \\
\text { masyarakat }\end{array}$ & $\begin{array}{l}\text { Orangtua murid, lembaga desa, } \\
\text { KTBT Pulau Damer, tokoh agama } \\
\text { serta pemuka masyarakat. }\end{array}$ & $\begin{array}{l}\text { Otangtua murid, lembaga desa, } \\
\text { KTBT Pulau Damer, tokoh agama } \\
\text { serta pemuka masyarakat. }\end{array}$ \\
\hline 3 & $\begin{array}{l}\text { Pembuatan program untuk } \\
\text { meningkatkan partisipasi } \\
\text { masyarakat }\end{array}$ & $\begin{array}{l}\text { Menganalisis permasalahan, } \\
\text { menganalisis potensi yang } \\
\text { telah dimiliki, serta } \\
\text { kepentingan atau kemaun } \\
\text { warga masyarakat } \\
\text { dianalisis. }\end{array}$ & $\begin{array}{l}\text { Menganalis setiap permasalahan } \\
\text { yang muncul, menganalisis segala } \\
\text { potensi yang ada serta kebutuhan- } \\
\text { kebutuhan dianalisis. }\end{array}$ & $\begin{array}{l}\text { Menganalisis permasalahan yang } \\
\text { sedang muncul, menganalisis } \\
\text { segala potensi yang dipinyai dan } \\
\text { menganalisis segala kebutuhan } \\
\text { kemauan dan kepentingan warga } \\
\text { masyarakat }\end{array}$ \\
\hline 4 & $\begin{array}{l}\text { Teknik pelaksanaan } \\
\text { partisipasi masyarakat }\end{array}$ & $\begin{array}{l}\text { Mengakui adanya } \\
\text { keberadaan warga } \\
\text { masyarakat, menumbuhkan } \\
\text { rasa memiliki, melakukan } \\
\text { kunjungan rutin ke rumah } \\
\text { orangtua murid, } \\
\text { membangun citra postif, } \\
\text { menumbuhkan kepercayaan } \\
\text { warga masyarakat, serta } \\
\text { melibatkan tokoh-tokoh } \\
\text { warga masyarakat }\end{array}$ & $\begin{array}{l}\text { Memberikan tanggung jawab lebih } \\
\text { kepada warga masyarakat atas } \\
\text { setiap kegiatan disekolah, } \\
\text { Segala kelebihan serta kekuatan } \\
\text { yang telah sekolah miliki } \\
\text { disebarluaskan, dalam setiap } \\
\text { kegiatan sekolah tokoh-tokoh } \\
\text { masyarakat diikutsertakan, serta } \\
\text { untuk selalu memberikan } \\
\text { memberikan masukan, kritik serta } \\
\text { saran untuk dapat membangun } \\
\text { sekolah, warga masyarakat } \\
\text { diberikan pelung yang luas. }\end{array}$ & $\begin{array}{l}\text { Mengakui keberadaan setiap } \\
\text { warga masyarakat dengan } \\
\text { memberikan tanggung jawab } \\
\text { kepada mereka atas segala } \\
\text { kegiatan yang diselenggarakan } \\
\text { disekolah, menumbuhkan rasa } \\
\text { ingin memiliki, menumbuhkan } \\
\text { rasa kepeercayaan kepada warga } \\
\text { masyarakat, menyebarluaskan } \\
\text { segala bentuk kelebihan dan } \\
\text { kekuatan yang telah dimiliki oleh } \\
\text { pihak sekolah, mengikutsertakan } \\
\text { dan melbatkan tokoh-tokoh } \\
\text { masyarakat dalam kegiatan yang } \\
\text { diadakan sekolah, dan } \\
\text { memberikan peluas yang luas dan } \\
\text { seluas-luasnya kepada warga } \\
\text { masyarakat untuk selalu dapat } \\
\text { memberikan masukan, saran dan } \\
\text { kritik bagi sekolah guna } \\
\text { membangun sekolah }\end{array}$ \\
\hline 5 & $\begin{array}{l}\text { Tingkat partisipasi } \\
\text { masyarakat }\end{array}$ & Placation & Placation & Placation \\
\hline
\end{tabular}


Tabel 1. Temuan Lintas Situs Penelitian (Lanjutan

\begin{tabular}{|c|c|c|c|}
\hline $\begin{array}{l}6 \text { Hasil dan dampak } \\
\text { partisipasi masyarakat }\end{array}$ & $\begin{array}{l}\text { Dampak bagi sekolah: } \\
\text { pembangunan perpustakaan } \\
\text { sekolah, pembuatan kantin } \\
\text { sekolah, pembangunan } \\
\text { kamar mandi/wc bagi guru } \\
\text { dan siswa-siswi dan } \\
\text { peningkatan kualitas guru- } \\
\text { guru. } \\
\text { Dampak bagi warga } \\
\text { masyarakat: sekolah } \\
\text { semakinterbuka, prestasi } \\
\text { belajar siwa semakin } \\
\text { meningkat, tangung jawab } \\
\text { terhadap penyelenggaraan } \\
\text { pendidikan semakin } \\
\text { meningkat. }\end{array}$ & $\begin{array}{l}\text { Bagi sekolah: meningkatnya } \\
\text { prestasi belajar siswa, } \\
\text { meningkatnya kepercayaan } \\
\text { stakeholder kepada pihak sekolah, } \\
\text { dan adanya pembangunan ruang } \\
\text { kelas, perbaikan ruang guru, } \\
\text { pembangunan wc/kamar mandi bagi } \\
\text { siswa dan guru, serta meningkatnya } \\
\text { kualitas guru-guru. } \\
\text { Bagi masyarakat: sekolah terbuka, } \\
\text { keputusan yang dibuat mewakili } \\
\text { aspirasi masyarakat, meningkatnya } \\
\text { kuantitas masukan untuk } \\
\text { peningkatan mutu pendidikan di } \\
\text { sekolah }\end{array}$ & $\begin{array}{l}\text { Hasil dan dampak dari partisipasi } \\
\text { masyarakat terhadap kedua } \\
\text { sekolah dapat sekali dirasakan } \\
\text { oleh warga masyarakat dan pihak } \\
\text { sekolah }\end{array}$ \\
\hline
\end{tabular}

\section{PEMBAHASAN}

\section{Jenis Partisipasi yang dibutuhkan Sekolah dari Masyarakat}

Berdasarkan hasil temuan pada analisis lintas situs diperoleh pemahaman bahwa kedua sekolah mendapati jenis partisipasi yang hampir sama, yaitu berupa uang atau dana, ide pikiran, dan tenaga yang semuanya digunakan untuk membangun dan meningkatkan taraf pembelajaran di kedua sekolah. Temuan ini membenarkan pernyataan dari teori (Ratiabriani, Bagus, \& Purbadharmaja, 2016) yang mengelompokkan jenis partisipasi menjadi dua, yaitu partisipasi secara aktif dan pasif. Bentuk partisipasi pasif ialah dukungan berupa sikap, perilaku, dan tindakan dengan tidak mengganggu jalannya penyelenggaraan pembuatan program pendidikan oleh masyarakat, sedangkan partisipasi aktif adalah melibatkan langsung dirinya dalam setiap kegiatan yang diselenggarakan. Dalam penelitian ini, bentuk partisipasi yang diberikan adalah pasif dan aktif yang terlihat pada kegiatan keikutsertaan masyarakat dalam membangun dan tidak mengganggu jalannya pembangunan. Keterlibatan peran serta masyarakat dalam temuan ini memberikan gambaran bahwa lembaga pendidikan juga memberikan wewenang kepada masyarakat yang sebelumnya sudah ditetapkan dalam Undang-undang mengenai keberadaan masyarakat yang memiliki tanggung jawab pada pengembangan pembangunan pendidikan di daerahnya yang termasuk ke dalam proses disentralisasi Pendidikan (Purbathin, 2015).

Jenis partisipasi yang dapat diberikan oleh masyarakat juga meliputi dukungan yang bersifat nonmaterial, seperti motivasi dan lain sebagainya. Pernyataan ini sesuai dengan teori yang dipaparkan oleh (Purbathin, 2015) yang secara operasional pemberdayaan masyarakat juga memiliki dua kecenderuangan, yaitu kecenderungan primer dan sekunder. Kecenderungan primer, meliputi kekuasaan, kemampuan dan kekuatan, sedangkan kecenderungan sekunder, meliputi pemberian motivasi dan semangat kepada lembaga yang mengadakan partisipasi masyarakat.

\section{Unsur Masyarakat yang Berpastisipasi}

Masyarakat yang turut berpartisipasi dalam penyelenggaran sekolah melalui hasil temuan lintas situs ini, meliputi masyarakat sekitar, orangtua, tokoh penting di daerah tersebut, KTBT dan tokoh Agama, hasil temuan ini sesuai dengan teori yang dipaparkan oleh (Deviyanti, 2013) bahwa dalam mengadakan partisipasi masyarakat dalam setiap kegiatan, tentu suatu lembaga tidak memperhatikan tingkat maupun ekonomi masyarakatnya karena semua masyarakat dapat terlibat dalam pembangunan sekolah di daerahnya, oleh karenanya kedua sekolah tidak memberikan persyaratan mengenai unsur masyarakat yang bisa ikut terlibat dalam pembangunan sekolah sehingga semua masyarakat merasakan secara langsung tanggung jawabnya dalam membangun pendidikan. Teori ini dengan sangat jelas memberikan pemahaman bahwa suatu lembaga tidak harus mempertimbangkan jenis atau unsur masyarakat yang dapat terlibat, karena dalam Undang-undang pun masyarakat sebagai salah satu pihak yang bertanggung jawab dalam perkembangan pendidikan, digambarkan secara umum dan tidak dikelompokkan baik berdasarkan tingkat ekonomi, strata dan lain sebagainya.

Pada UU RI Nomor 20 tahun 2003 tentang Sisdiknas BAB IV yang memaparkan bahwa ada beberapa pihak yang memiliki tanggung jawab dalam pengembangan pendidikan, salah satu yang disebutkan adalah masyarakat. Teori ini memperkuat hasil temuan yang diperoleh pada kedua sekolah.

\section{Pembuatan Program untuk Meningkatkan Partisipasi Masyarakat}

Berdasarkan pada hasil temuan lintas situs mengenai pembuatan program melalui proses partisipasi masyarakat di dua sekolah, diperoleh pemahaman bahwa keduanya sepakat bahwa pembuatan program dilakukan dengan menganalisis permasalahan yang terjadi, menganalisis potensi atau sumber daya yang ada, kemudian mengetahui kebutuhan sekolah sehingga perlu diadakan peran serta masyarakat. Temuan ini sesuai dengan teori yang dipaparkan oleh (Rosyida \& Tonny Nasdian, 2011) 
bahwa dalam pembuatan program, ada beberapa hal yang perlu dilakukan seperti penerapan tahap perencanaan, pelaksanaan dan evaluasi. Ketiga tahap ini apabila dikaitkan ke dalam hasil temuan maka diperoleh proses perencanaan pada proses menganalisis yang dijelaskan, sedangkan untuk tahap pelaksanaan dan evaluasi dilakukan setelah tahap perencanaan selesai, untuk melihat perkembangan dalam pencapaian tujuan.

Menurut (Widjajanti, 2011) upaya pemberdayaan masyarakat dalam pembuatan program tentu sangat dipertimbangkan, karena keberadaan mereka sebelumnya sudah digambarkan dalam peraturan perundang-undangan, selain itu peran serta masyarakat dalam pembuatan program adalah dengan melibatkan dirinya secara langsung dalam pemberian gagasan, pikiran maupun masukan-masukan yang dapat dipertimbangkan dalam proses perancangan, dalam hal ini tentu yang dipertimbangkan adalah kebutuhan dan kemauan masyarakat yang selanjutnya akan direalisasikan untuk membangun dan menyelenggarakan sekolah di daerahnya. Teori ini menggambarkan posisi masyarakat secara global, yaitu partisipasi masyarakat dalam pembuatan program meliputi pemberian masukan-masukan sehingga dapat dianalisis oleh penyelenggaran program, hal yang diberikan masukan adalah untuk membangun sekolah dan mempelancar pendidikan. Berdasarkan pengertian dan hasil temuan tersebut maka yang terpenting dalam pembuatan program adalah dengan menganalisis kebutuhan, sehingga perencanaannya dapat mempertimbangkan hal lain yang juga dianggap sangat penting (Nuraeni, Rachim, \& Gutama, 2016).

\section{Teknik Pelaksanaan Partisipasi Masyarakat}

Tehnik pelaksanaan partisipasi masyarakat adalah dengan mengakui keberadan masyarakat sekitar daerah sekolah, memberikan tanggung jawab kepada masyarakat dalam hal pembangunan sekolah, melibatkan masyarakat dalam berbagai kegiatan, menumbuhkan kepercayaan, menyebarluaskan kelebihan dan kekuatan tentang pentingnya keberadaan sekolah untuk masa depan peserta didik, mengikutsertakan tokoh Agama atau tokoh penting dalam daerah tersebut sehingga memudahkan penyelenggaraan proses partisipasi, dan memberikan kebebasan kepada masyarakat untuk memberi masukan-masukan yang bersifat membangun untuk sekolah. Tehnik pelaksanaan yang disebutkan dalam hasil temuan lintas kasus ini menggambarkan bahwa kedua sekolah menggunakan tehnik melibatkan langsung masyarakat dalam pelaksanaan partisipasi, yaitu dengan memberikan pengertian dan kepercayaan kepada masyarakat sehingga masyarakt secara langsung merasa bahwa mereka mempunyai tanggung jawab pada pembangunan pendidikan.

Hasil di atas juga menguatkan teori yang dipaparkan oleh (Kadir, 2013) bahwa dalam melibatkan masyarakat harus menggunakan tehnik yang baik atau yang tidak merugikan pihak lain dan menguntungkan satu pihak saja, tehnik ini digunakan dengan mempertimbangkan keberadaan Agama, budaya dan kebiasaan masyarakat di daerah sekolah tersebut, yaitu dengan memberikan pemahaman kepada tokoh Agama atau yang penting dari daerah yang dimaksud sehingga mempermudah pengadaan kegiatan partisipasi dan pengumpulan masukan-masukan untuk pembuatan program pendidikan.

\section{Tingkat Partisipasi Masyarakat}

Tingkat partisipasi masyarakat yang dimaksud dalam penelitian ini adalah mencakup kesulitan dan kemudahan dalam menyelenggarakan kegiatan peran serta atau partisipasi masyarakat, dan berdasarkan pada hasil temuan penelitian diperoleh pemahaman bahwa tingkat partisipasi masyarakat dalam penyelenggaraan sekolah oleh kedua situs adalah sedang (placation), hal ini karena kedua sekolah baik dalam proses pengumpulan, pembuatan dan pelaksanaan penyelenggaraan sekolahnya dapat dikatakan tidak terlalu sulit karena kedua melibatkan tokoh penting dan tokoh Agama yang tentunya sangat dihargai, sehingga mempermudah pelaksanaan kegiatan. Temuan ini membuktikan teori yang dipaparkan oleh (Prayitno, 2008) bahwa tingkatan dalam partisipasi masyarakat dapat dikatakan mudah apabila dalam penyelenggaraannya semua kebutuhan dalam menyelenggarakan sekolah sangat mudah dijangkau, kebutuhan yang dimaksud dapat berupa jenis partisipasi yang diberikan oleh masyarakat seperti dana, ide atau pemikiran, tenaga dan lain sebagainya. Tenaga yang dimaksud tentu dilakukan dengan pelibatan secara langsung atau ikut serta dalam melaksanakan pembuatan, pelaksanaan dan pengevaluasian program dalam menyelenggarakan sekolah demi meningkatkan mutu sekolah.

Hal yang sama kemudian dijelaskan oleh (Firmansyah, 2012) bahwa tingkat partisipasi masyarakat dapat dikelompokkan menjadi empat, yaitu tingkat kesadaran, kemampuan dalam meningkatkan kapasitas, tingkat kemampuan menghadapi hambatan, dan tingkat kemampuan mengadakan kerjasama, apabila keempat tingkat ini dilakukan dengan baik tanpa ada halangan yang cukup berat maka dapat dipastikan bahwa penyelenggaraan sekolah akan berjalan lancar. Teori ini memberikan pemahaman mengenai hasil temuan bahwa tingkat partisipasi masyarakat kedua sekolah dinilai sedang karena dalam pelaksanaanya tidak terlalu sulit ataupun mudah sehingga berada di tingkat sedang.

\section{Hasil dan Dampak Partisipasi Masyarakat}

Hasil dan dampak yang terlihat melalui penelitian yang diperoleh pada temuan lintas situs kedua sekolah ini adalah berupa pembangunan fasilitas-fasilitas sekolah, seperti ruangan kelas, ruang guru, dan kamar mandi serta harapan kedepannya adalah pembangunan fasilitas lainnya yang dapat menunjang peningkatan mutu pendidikan. Hasil temuan ini memperkuat teori yang dipaparkan oleh (Coryanata, 2007) bahwa salah satu hasil dan dampak yang diperoleh dari pelaksanaan program dan partisipasi masyarakat adalah tercapainya penyelenggaran sekolah yang bersifat transparansi atau secara fisik dapat disaksikan dan dinikmati oleh orang banyak. 
Teori di atas memberikan pernyataan yang sangat jelas mengenai hasil dan dampaknya dapat dirasakan langsung oleh masyarakat sekolah melalui pembuatan, pelaksanaan dan evaluasi program yang diperoleh melalui kegiatan partisipasi atau peran serta masyarakat dalam penyelenggaran sekolah dan meningkatkan mutu pendidikan yang ada di kedua sekolah, hasilnya adalah berbentuk pemberian dana, tenaga dan pikiran untuk memberikan masukan-masukan demi membangun pengembangan sekolah di daerahnya.

\section{SIMPULAN}

Pembahasan yang akan diuraikan pada kesimpulan dan saran bagi pelaksana pendidikan yang berkaitan dengan manajemen partisipasi masyarakat dalam penyelenggaraan sekolah di daerah terpencil, setelah ditemukan temuan penelitian lintas situs pada bab-bab sebelumnya. Pertama, jenis partisipasi yang dibutuhkan oleh sekolah didaerah terpencil seperti pikiran, uang, tenaga, fasilitas, dan barang-barang yang dimiliki warga masyarakat di sekitar lingkungan sekolah. Kedua, unsur masyarakat yang berpartisipasi tehadap sekolah didaerah terpencil adalah orangtua murid, lembaga desa, KTBT Pulau Damer, pemuka-pemuka masyarakar dan tokoh-tokoh agama. Ketiga, melalui langkah-langkah, seperti (a) menganalisis permasalahan yang muncul, (b) menganalisis potensi yang dimiliki sekolah, dan (c) menganalisis kebutuhan, kepentingan dan kemauan masyarakat adalah langkah-lanfkah yang dilakukan untuk pembuatan program perencanaan untuk meningkatkan partisipasi masyarakat terhadap sekolah di daerah terpencil.

Keempat, teknik-teknik seperti (a) mengakui keberadaan masyarakat dengan memberikan tanggung jawab kepada mereka atas kegiatan di sekolah, (b) menumbuhkan rasa memiliki, (c) menumbuhkan rasa kepercayaan diri masyarakat, (d) melibatkan tokoh-tokoh masyarakat, (e) menyebarluaskan segala kelebihan dan kekuatan yang telah dimiliki sekolah, dan (f) memberikan peluang yang luas kepada masyarakat untuk selalu memberikan masukan, saran dan kritik kepada pihak sekolah merupakan teknik-teknik yang harus dilakukan dalam melaksanakan partisipasi masyarakat terhadap sekolah di daerah-daerah terpencil. Kelima, tingkat placation merupakan tingkat partisipasi masyarakat yang terjadi di sekolah daerah-daerah terpencil. Warga masyarakat memang mempunyai pengaruh hanya saja tidak menjadi jaminan untuk diperhatikan. Keenam, dampak yang dirasakan oleh pihak sekolah, yakni (a) dibangunnya ruang pembelajaran, dan fasilitas penunjang pembelajaran, seperti wc/kamar mandi bagi siswa dan guru, dan perpustakaan, (b) peningkatan motivasi dan kompetensi guru-guru, (c) peningkatan kepercayaan warga masyarakat kepada pihak sekolah, (d) meningkatnya tanggung jawab masyarakat terhadap pendidikan di sekolah, dan (e) semakin meningkatnya prestasi belajar peserta didik. Ada juga dampak-dampak yang dirasakan oleh warga masyarakat itu sendiri, yakni (a) sekolah semakin terbuka, (b) prestasi belajar peserta didik mengalami peningkatan, (e) setiap keputusan yang dibuat mewakili aspirasi warga masyarakat, dan (d) secara tidak langsung penghasilan warga masyarakat mengalami peningkatan.

Saran yang dapat dikemukakan oleh peneliti dalam penelitian ini, sebagai berikut. Pertama, Dinas pendidikan, Pemuda dan Olaraga Kabupaten Maluku Barat Daya, agar dapat melakukan koordinasi yang baik dengan Kementrian Pendidikan dan Kebudayaan, Dasar dan Menengah supaya dapat menganalisis dan dapat menyalurkan bantuan kepada sekolah-sekolah yang berada di daerah terpencil khususnya di Pulau Damer. Kedua, koordinator Wilayah SD/SMP di Kecamatan Damer, agar dapat menghimbau tiap-tiap sekolah untuk membuat program yang lebih banyak melibatkan partisipasi warga masyarakat hingga tercapainya tingkat partnership. Ketiga, kepala sekolah di kedua sekolah bahkan sekolah-sekolah yang lain, agar dapat menggalih macam-macam bentuk partisipasi yang lain seperti bantuan jasa dan penyusunan program untuk membentuk paguyupan orangtua murid agar partisipasi masyarakat dapat mencapai tingkat partnership. Keempat, guru-guru melakukan kunjungan yang intensif untuk mengunjungi rumah-rumah orangtua murid untuk menjalin hubungan yang lebih baik agar partisipasi masyarakat dalam bentuk dukungan moral semakin meningkat dan dapat berdampak pada peningkatan prestasi belajar peserta didik. Kelima, masyarakat dapat meningkatkan partisipasi secara aktif dalam bentuk bantuan materi, jasa, ide dan moral yang sesuai dengan kebutuhan di sekolah. Keenam, peneliti lain dapat melakukan penelitian yang sama maupun peneliti lain dapat melanjutkan penelitian ini dengan pendekatan yang berbeda demi menambah wawasan dan ilmu tentang manajemen partisipasi masyarakat dalam penyelenggaraan sekolah di daerah terpencil.

\section{DAFTAR RUJUKAN}

Deviyanti, D. (2013). Studi Tentang Partisipasi Masyarakat Dalam Pembangunan di Kelurahan Karang Jati Kecamatan Balikpapan Tengah. E-Journal Administrasi Negara, 1(2), 380-394.

Dwiningrum, S. I. A. (2011). Desentralisasi dan Partisipasi Masyarakat dalam Pendidikan. Yogyakarta: Pustaka Belajar.

Firmansyah, H. (2012). Tingkat Keberdayaan Masyarakat dalam Program Pemberdayaan Masyarakat di Kota Banjarmasin dan Kabupaten Tanah Laut. Jurnal Agribisnis Perdesaan, 2(1), 53-67.

Hadi, A. P. (2015). Konsep Pemberdayaan, Partisipasi dan Kelembagaan Dalam Pembangunan. Yayasan Agribisnis/Pusat Pengembangan Masyarakat Agrikarya, 1(1), 1-14.

Handayani, R. (2011). Analisis Partisipasi Masyarakat Dan Peran Pemerintah Daerah Dalam Pelaksanaan Manajemen Bencana di Kabupaten Serang Provinsi Banten. 1(2). Simposium Nasional Otonomi Daerah: http://lab-ane.fisip-untirta.ac.id/wpcontent/uploads/2011/06/33\%20riny\%20handayani.pdf 
Hermawan, Y., \& Suryono, Y. (2016). Partisipasi Masyarakat dalam Penyelenggaraan Program-Program Pusat Kegiatan Belajar Masyarakat Ngudi Kapinteran. Jurnal Pendidikan dan Pemberdayaan Masyarakat, 3(1), 97-108. https://doi.org/10.21831/jppm.v3i1.8111 Proceeding Simposium Nasional Otonomi Daerah 201

Imron, A. (2012). Kebijaksanaan Pendidikan di Indonesia: Proses, Produk \& Masa Depannya. Jakarta: Bumi Aksara.

Isma Coryanata. (2007). Akuntabilitas, Partisipasi Masyarakat, dan Transparansi Kebijakan Publik sebagai Pemoderating Hubungan Pengetahuan Dewan tentang Anggaran dan Pengawasan Keuangan Daerah (APBD). 1(2). Simposium Nasional Akuntansi X. https://doi.org/10.1017/CBO9781107415324.004

Kadir, S. F. (2013). Meningkatkan Mutu Pendidikan Melalui Pemberdayaan Masyarakat. Jurnal Al-Ta-Dib, 6(1), $164-175$.

Laksana, N. S. (2013). Bentuk-Bentuk Partisipasi Masyarakat Desa dalam Program Desa Siaga di Desa Bandung Kecamatan Playen Kabupaten Gunung Kidul Provinsi Daerah Istimewa Yogyakarta. Skripsi tidak diterbitkan. Universitas Negeri Yogyakarta, Yogyakarta.

Lukito, R. (2012). Manajemen Peran Serta Masyarakat dalam Peningkatan Mutu Pendidikan. Disertasi tidak diterbitkan. Universitas Negeri Malang, Malang.

Magriasti, L. (2011). Arti Penting Partisipasi Masyarakat dalam Kebijakan Publik di Daerah : Analisis dengan Teori Sistem David Easton. 1(1). Proceeding Simposium Nasional Otonomi Daerah 2011: http://www.academia.edu/download/31087489/48-90-1-SM.pdf

Mariana, D. (2017). Partisipasi Masyarakat Dalam Proses Kebijakan. CosmoGov: Jurnal Ilmu Pemerintahan, 2(1), $216-229$. https://doi.org/10.24198/cosmogov.v1i2.11834

Moleong, L. (2016). Metode Penelitian Kualitatif. Bandung: PT Remaja Rosdakarya.

Munadi, M. (2008). Partisipasi Masyarakat dalam Pengambilan Kebijakan Publik Bidang Pendidikan di Kota Surakarta. Jurnal Penelitian dan Evaluasi Pendidikan, 12(2), 268-284.

Nuraeni, S. H., Rachim, H. A., \& Gutama, A. S. (2016). Partisipasi Masyarakat Dalam Mendukung Pelaksanaan Pendidikan Inklusif untuk Anak Berkebutuhan Khusus. Prosiding Penelitian dan Pengabdian Kepada Masyarakat, 2(3). https://doi.org/10.24198/jppm.v3i2.13653

Prayitno, D. (2008). Partisipasi Masyarakat Dalam Implementasi Kebijakan Pemerintah. Tesis tidak diterbitkan. Universitas Diponegoro, Semarang.

Ratiabriani, N. M., \& Purbadharmaja, I. B. P. (2016). Partisipasi Masyarakat dalam Program Bank Sampah: Model Logit. Jurnal Ekonomi Kuantitatif Terapan, 9(1), 53-58.

Rosyida, I., \& Nasdian, F. T. (2011). Partisipasi Masyarakat Dan Stakeholder Dalam Penyelenggaraan Program Corporate Social Responsibility (CSR) dan Dampaknya terhadap Komunitas Perdesaan. Sodality: Jurnal Sosiologi Pedesaan, 5(1), 51-70. https://doi.org/10.22500/sodality.v5i1.5832

Sugiyono. (2014). memahami metode kualitatif. Bandung: Alfabeta.

Suroso, H., Hakim, A., \& Noor, I. (2014). Faktor-Faktor yang Memengaruhi Partisipasi Masyarakat Dalam Perencanaan Pembangunan di Desa Banjaran Kecamatan Driyorejo Kabupaten Gresik. Wacana: Jurnal Sosial dan Humaniora, 17(1), 7-15.

Ulfatin, N. (2015). Metode Penelitian Kualitatif di Bidang Pendidikan: Teori dan Aplikasinya. Malang: Media Nusa Creative.

Widjajanti, K. (2011). Model Pemberdayaan Masyarakat. Jurnal Ekonomi Pembangunan: Kajian Masalah Ekonomi dan Pembangunan, 12(1), 15-27. https://doi.org/10.23917/jep.v12i1.202

Zaini, A., Zakso, A., \& Syukri, M. (2014). Partisipasi masyarakat dalam penyelenggaraan pendidikan. Jurnal Pendidikan dan Pembelajaran, 3(11), 1-13. 